\title{
ALK alterations in salivary gland carcinomas
}

\author{
Hanna Majewska ${ }^{1}$ - Adam Gorczyński ${ }^{1}$ - Piotr Czapiewski ${ }^{1} \cdot$ Roopika Menon $^{2}$ - Judith Mueller ${ }^{2}$ - Sotirios Lakis ${ }^{2}$. \\ Johannes M. Heuckmann ${ }^{2} \cdot$ Jan Laco $^{3} \cdot$ Ruta Gupta $^{4} \cdot$ Simon Andreasen $^{5} \cdot$ Dominik Stodulski $^{6} \cdot$ Mariola lliszko $^{7}$. \\ Rafał Dziadziuszko ${ }^{8} \cdot$ Jacek Jassem $^{8} \cdot$ Lukas C. Heukamp $^{9} \cdot$ Wojciech Biernat ${ }^{1}$
}

Received: 2 August 2020 / Revised: 25 October 2020 / Accepted: 15 November 2020 / Published online: 25 November 2020

(C) The Author(s) 2020

\begin{abstract}
Salivary gland carcinomas represent a heterogeneous group of poorly characterized head and neck tumors. The purpose of this study was to evaluate $A L K$ gene and protein aberrations in a large, well-characterized cohort of these tumors. A total of 182 salivary gland carcinomas were tested for anaplastic lymphoma kinase (ALK) positivity by immunohistochemistry (IHC) using the cut-off of $10 \%$ positive cells. ALK positive tumors were subjected to FISH analysis and followed by hybrid capture-based next generation sequencing (NGS). Of the 182 tumors, 8 were ALK positive by IHC. Further analysis using hybrid capture NGS analysis revealed a novel MYO18A (Exon1-40)-ALK (exon 20-29) gene fusion in one case of intraductal carcinoma. Additional genomic analyses resulted in the detection of inactivating mutations in $B R A F$ and TP53, as well as amplifications of ERBB2 and $A L K$. $A L K$ rearrangements are a rare entity in salivary gland carcinomas. We identified a potentially targetable novel $A L K$ fusion in an intraductal carcinoma of minor salivary glands.
\end{abstract}

Keywords Anaplastic lymphoma kinase · Salivary gland carcinoma · Intraductal carcinoma $\cdot$ FISH $\cdot$ Immunohistochemistry · Next generation sequencing

\section{Introduction}

Salivary gland tumors comprise a heterogeneous group of benign and malignant neoplasms, accounting for approximately $6 \%$ of all head and neck cancers. Salivary gland carcinomas (SGCs) are rare and characterized by extensive morphological diversity and variable clinical behavior [1].

Molecular genetic studies have recently revealed that gene rearrangements play a significant role in the molecular pathogenesis of SGCs [1]. These translocations are associated with

Dr. Sotirios Lakis is no longer an employee of New Oncology

Wojciech Biernat

biernat@gumed.edu.pl

1 Department of Pathomorphology, Medical University of Gdańsk, ul. Smoluchowskiego, 17 80-211 Gdańsk, Poland

2 NEO New Oncology GmbH, Cologne, Germany

3 The Fingerland Department of Pathology, Charles University Faculty of Medicine in Hradec Kralove and University Hospital Hradec Kralove, Hradec Kralove, Czech Republic

4 Department of Tissue Pathology and Diagnostic Oncology, University of Sydney, Sydney, Australia specific histological subtypes or with particular morphological patterns. For instance, the translocations $\mathrm{t}(11 ; 19)$ and $\mathrm{t}(11 ; 15)$, resulting in CRTC1-MAML2 or CRTC3-MAML2 fusion oncogenes, respectively, are relatively common in mucoepidermoid carcinomas (MECs) originating in diverse anatomical locations [2-4]. ETV6-NTRK3 and ETV6-RET translocation was found to be specific for secretory carcinoma (a.k.a. mammary analogue secretory carcinoma, MASC) and has not been documented in any other salivary gland tumor $[5$, 6]. Around $80-90 \%$ of adenoid cystic carcinomas (AdCC)

5 Department of Otorhinolaryngology and Maxillofacial Surgery, Køge University Hospital, Køge, Denmark

6 Department of Otolaryngology, Medical University of Gdańsk, Gdańsk, Poland

7 Department of Biology and Medical Genetics, Medical University of Gdańsk, Gdańsk, Poland

8 Department of Oncology and Radiotherapy, Medical University of Gdańsk, Gdańsk, Poland

9 Institute of Hematopathology Hamburg, Hamburg, Germany 
reveal $M Y B$ or $M Y B L 1$ activation by gene fusion, leading to overexpression of MYB-NFIB or MYBL1-NFIB fusion protein, respectively $[3,7,8]$. Rearrangements of $E W S R 1$ were found in some tumors with clear cell morphology (e.g., in hyalinizing clear cell carcinoma (HCCC) and clear cell odontogenic carcinoma [CCOC]) and, most recently, in a subset of clear cell myoepithelial carcinoma (CCMC) characterized by more aggressive clinical behavior $[9,10]$. These alterations are functionally and clinically important biomarkers and may be considered new targets for personalized therapies.

ALK is a tyrosine kinase receptor that was originally described in 1994 by Morris et al. [11] in anaplastic large cell lymphoma (ALCL). Since then, its aberrations, such as rearrangements and gene copy number gains, have been found in many other malignant and benign neoplasms, e.g., EML4$A L K$ translocations occurring in $2-7 \%$ of lung adenocarcinomas [12]. There has been a growing interest in the pathogenic role of ALK alterations in other malignancies, as patients with ALK-positive tumors may benefit from therapies with ALK tyrosine kinase inhibitors. These alterations have been identified, among others, in benign fibrous histiocytoma [13], papillary thyroid carcinoma [14, 15], sarcomatoid carcinoma of the head and neck [16], and pediatric kidney carcinoma [17]. Likewise, there have been described five SGCs with $A L K$ alterations until now: a myoepithelial carcinoma with $M S N-A L K$ rearrangement [18], a secretory carcinoma with CTNNA1-ALK rearrangement [19], an intraductal carcinoma with $S T R N-A L K$ rearrangement [20], and two salivary gland carcinomas - one with HNRNPH3-ALK and another with $E M L 4-A L K$ gene fusion [21]. Therefore, we systematically evaluated ALK by immunohistochemistry (IHC) followed by dual color fluorescence in situ hybridization (FISH) and new generation sequencing (NGS) in IHCpositive cases in a large, well-characterized series of salivary gland carcinomas.

\section{Materials and methods}

The study material comprised the consecutive historical series of primary carcinomas of major and minor salivary glands resected at the Medical University of Gdańsk (Departments of Otolaryngology and Maxillofacial Surgery) between 1992 and 2012. A total of 182 salivary gland carcinomas (Table 1, Supplementary Table S1) was reviewed and reclassified according to the criteria published by WHO in 2017, with application of molecular testing, if necessary [5, 22]. After obtaining preliminary results, seven additional intraductal carcinomas were included into the study as obtained from the collections of some authors (SA, case nos. 1-3; RS, case no. 4; JL, case nos. 5-6; RG, case no. 7).

In all cases, paraffin blocks and recuts were available for histological, IHC, and molecular analysis.

\section{Tissue microarrays}

Tissue microarrays (TMAs) were generated from formalinfixed paraffin-embedded (FFPE) surgical resection tumor specimens $(n=182)$ and control samples (tonsils $n=2$, liver $n=1$, ALK positive adenocarcinoma of the lung $n=1$ ). Briefly, morphologically representative areas of tumors were targeted on H\&E sections of donor blocks. Four 1.0-mm cores were obtained from each tumor and brought into a recipient paraffin block forming microarray blocks using tissuearraying instrument (MTA-I, Beecher Instruments).

\section{Immunohistochemical analysis}

For IHC, 4- $\mu$ m-thick TMA sections were cut, mounted on silanized slides, and subjected to heat-induced epitope retrieval by immersion in EnVision Flex Target Retrieval Solution, High $\mathrm{pH}$, at $\mathrm{pH} 9$, at $97{ }^{\circ} \mathrm{C}$ in the PT Link (Dako) for $20 \mathrm{~min}$. The staining was performed by Autostainer Link 48, DAKO, with the use of primary mouse monoclonal anti-ALK antibody (clone 5A4, NCL-ALK, Novocastra) according to the manufacturer's instructions. Briefly, endogenous peroxidase was blocked by a 5-min treatment with EnVision Flex Peroxidase-Blocking Reagent. To visualize the reaction, the EnVision Flex/HRP (30 min) and DAB substrate working solution $(10 \mathrm{~min})$ were used. Finally, the slides were counterstained with hematoxylin. An appropriate positive control (one case of ALK-positive adenocarcinoma of the lung) was included in the staining procedure.

Table 1 Salivary gland carcinomas analyzed in the study

\begin{tabular}{ll}
\hline Histopathologic type & Number of cases $(\%)$ \\
\hline Adenoid cystic carcinoma & $61(33.5 \%)$ \\
Mucoepidermoid carcinoma & $23(12.6 \%)$ \\
Carcinoma ex pleomorphic adenoma & $24(13 \%)$ \\
Acinic cell carcinoma & $15(8.2 \%)$ \\
Adenocarcinoma not otherwise specified & $10(5.5 \%)$ \\
Salivary duct carcinoma & $10(5.5 \%)$ \\
Polymorphous adenocarcinoma & $7(3.8 \%)$ \\
Mammary analogue secretory carcinoma & $7(3.8 \%)$ \\
Epithelial-myoepithelial carcinoma & $6(3.3)$ \\
Basal cell adenocarcinoma & $4(2.2 \%)$ \\
Undifferentiated carcinoma & $3(1.6 \%)$ \\
Squamous cell carcinoma & $3(1.6 \%)$ \\
Myoepithelial carcinoma & $2(1.1 \%)$ \\
Neuroendocrine carcinoma & $2(1.1 \%)$ \\
Papillary cystadenocarcinoma & $2(1.1 \%)$ \\
Lymphoepithelial carcinoma & $1(0.5 \%)$ \\
Cribriform adenocarcinoma & $1(0.5 \%)$ \\
Intraductal carcinoma & $1(0.5 \%)$ \\
\hline
\end{tabular}


The IHC staining of ALK was expressed as the percentage of cells with positive staining, considering different cellular compartments (membranous, cytoplasmic, and nuclear). The intensity of staining was graded as follows: 0 for absent, 1 weak, 2 moderate, and 3 strong. Staining was considered positive if it was moderate to strong and detected in more than $10 \%$ of neoplastic cells in any compartment.

\section{FISH}

Eight SGC samples being ALK-positive by IHC in more than $10 \%$ of cells were subjected to dual color break apart FISH analysis. The 4- $\mu \mathrm{m}$-thick FFPE sections were cut and mounted on silanized slides. The 4- $\mu \mathrm{m}$-thick FFPE sections were cut and mounted on silanized slides. Hybridization was carried out according to the protocol provided by the manufacturer, using the VYSIS LSI ALK Dual Color Break Apart FISH Probe (Abbott Molecular, Abbott Park, IL, USA). The slides were deparaffinized in xylene, dehydrated by gradient alcohol, and rehydrated in deionized water, heated in the $\times 1$ target retrieval solution (pH 6) (DAKO, Glostrup, Denmark) for $120 \mathrm{~min}$ at 60 ${ }^{\circ} \mathrm{C}$ and subsequently cooled for $20 \mathrm{~min}$ at room temperature in the same solution. The slides were washed in deionized water for $5 \mathrm{~min}$ and immersed in the protease solution $(20 \mathrm{mg} / \mathrm{ml})$ for $20 \mathrm{~min}$ at $37^{\circ} \mathrm{C}$. Subsequently, they were placed into deionized water for $3 \mathrm{~min}$, dehydrated in a series of ethanol solution $(70 \%$, $85 \%$, and $96 \%$ for $2 \mathrm{~min}$ each), and air-dried. An appropriate amount of FISH probe was applied onto each specimen, which was then covered with a glass cover slip and sealed with rubber cement. The slides were incubated in the HYBrite ${ }^{\mathrm{TM}}$ instrument (Vysis) with co-denaturation parameters at $73{ }^{\circ} \mathrm{C}$ for $3 \mathrm{~min}$ and hybridization parameters at $37^{\circ} \mathrm{C}$ for $14 \mathrm{~h}$. The rubber-cemented cover slips were then removed, and the slides were placed in a post-hybridization wash solution $(2 \mathrm{xSSC} / 0.3 \% \mathrm{NP}-40)$ at $74{ }^{\circ} \mathrm{C}$ for $2 \mathrm{~min}$. The slides were air-dried in the dark, counterstained with DAPI II (VYSIS/Abbott), cover slipped, and immediately examined.

Hybridized slides were examined with an Imaginer Z2 (Zeiss, Germany) fluorescence microscope using a $\times 100 \mathrm{ob}-$ jective and filter sets, triple band pass (DAPI/Spectrum Green/ Spectrum Orange), dual band pass (FITC/Texas Red), and single band pass (Spectrum Green or Spectrum Orange). One hundred randomly selected non-overlapping tumor cell nuclei were examined for the presence of green and red fluorescent signals. Samples were classified as positive for ALK rearrangement if $15 \%$ or more of nuclei showed split signals (e.g., red and green signals were separated by $\geq 2$ signal diameters) or single red signals ( $\left.3^{\prime} \mathrm{ALK}\right)$.

\section{Next generation sequencing}

Genomic DNA was extracted from the salivary gland FFPE block, sheared (Covaris), and subjected to hybrid capture- based NGS panel of 79 genes (Supplementary Table S2) to detect point mutations, small insertions and deletions, copy number alterations, and genomic rearrangements in a single assay (NEO New Oncology GmbH, Cologne, Germany). Briefly, after shearing, adapters were ligated, and individual genomic regions of interest were enriched using complementary bait sequences (hybrid capture procedure). The selected baits ensure optimal coverage of all relevant genomic regions. After enrichment, all targeted fragments were amplified (clonal amplification) and sequenced in parallel at high sequencing depth. Computational analysis was performed using NEO New Oncology's proprietary computational biology analysis to detect relevant genomic alterations in a quantitative manner.

\section{Results}

\section{Clinical and histopathologic data of ALK FISH-positive tumor}

The only $A L K$-rearranged tumor occurred in the minor salivary gland of the upper lip of a 73-year-old female. Her previous medical history was non-contributory. The tumor was palpable for about 10 years and was painful under pressure. The patient underwent radical tumor resection with clear surgical margins and is alive with no evidence of disease after 8 years of follow-up.

Histologically, this case featured a histomorphology of intraductal carcinoma (IC), intercalated duct type, and was characterized by predominantly macrocystic and microcystic with focally solid growth pattern; it had a multilobular architecture divided by thin or hyalinized fibrous septa (Fig. 1a-d). Intraluminal PAS-positive secretions were visible in some portions of the tumor (Fig. 1e). Tumor cells were diffusely positive for CK7, S100 protein, SOX10, and mammaglobin. The tumor islands were consistently surrounded by a layer of myoepithelial cells as determined by p63, CK14, and calponin expression. On high-power magnification, the tumor revealed bland cytological features, with tumor cells ranging from small to medium size. They had indistinct cell borders and round or ovoid nuclei with dark condensed or finely dispersed chromatin and large pale to eosinophilic cytoplasm. Isolated mucinous cell were scattered in the neoplasm (Fig. 1e). Proliferative activity was low, with a Ki67/MIB1 index $<5 \%$.

\section{Pathology, immunohistochemistry, and FISH}

Study material included 18 pathologic types of salivary gland tumors (Table 1). The IHC staining of the ALK protein was considered positive in eight cases (Table 2). The positive cases were subjected to FISH analysis and included the following tumor types: AdCC (three cases), basal cell carcinoma 
(BCAC, two cases), and one case each of myoepithelial carcinoma (MYEC), polymorphous adenocarcinoma (PAC), cribriform adenocarcinoma of minor salivary glands (CAMSG), intraductal carcinoma, and acinic cell carcinoma (AciCC). One case (intraductal carcinoma) displayed strong membranous expression of ALK in $100 \%$ of cells (Fig. 1f) and was subsequently shown to be positive for $A L K$ rearrangement by FISH analysis (Fig. 1g). The remaining seven cases were FISH negative.

In addition, 30 cases (16.5\%) showed weak to moderate staining in up to $10 \%$ of tumor cells. These cases were not further analyzed.

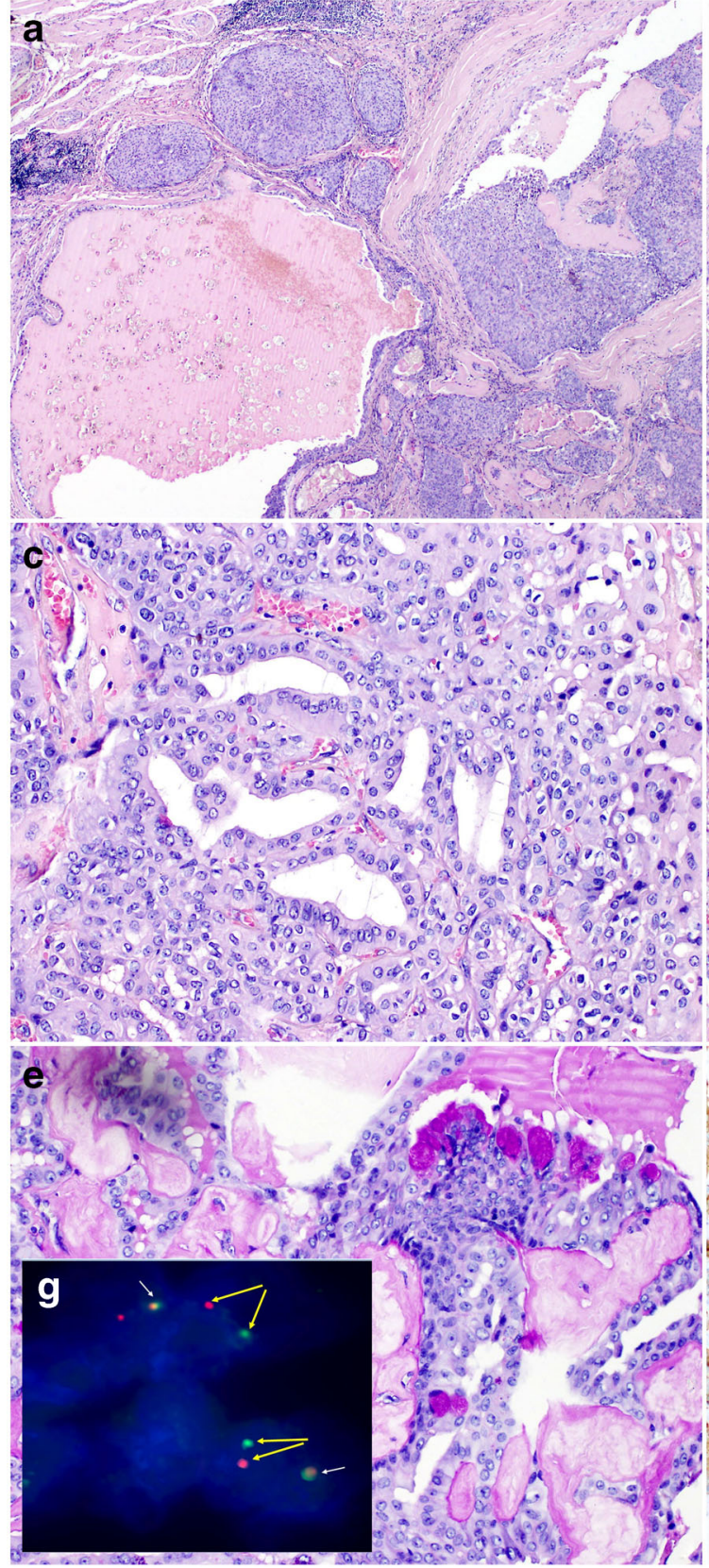

Fig. 1 Intraductal carcinoma. a The unencapsulated tumor composed of variably sized cysts and nests with mainly intraductal proliferations The neoplastic nests contain epithelioid cells with abundant eosinophilic cytoplasm and regular oval and round nuclei with conspicuous nucleoli $(H \& E \times 20)$. b The cysts contained micropapillary structures, solid areas with irregular fenestrations or cribriform areas $(H \& E \times 20)$. $\mathbf{c}-\mathbf{d}$ The neoplastic nests contain epithelioid cells with abundant eosinophilic cytoplasm and regular oval and round nuclei with conspicuous nucleoli

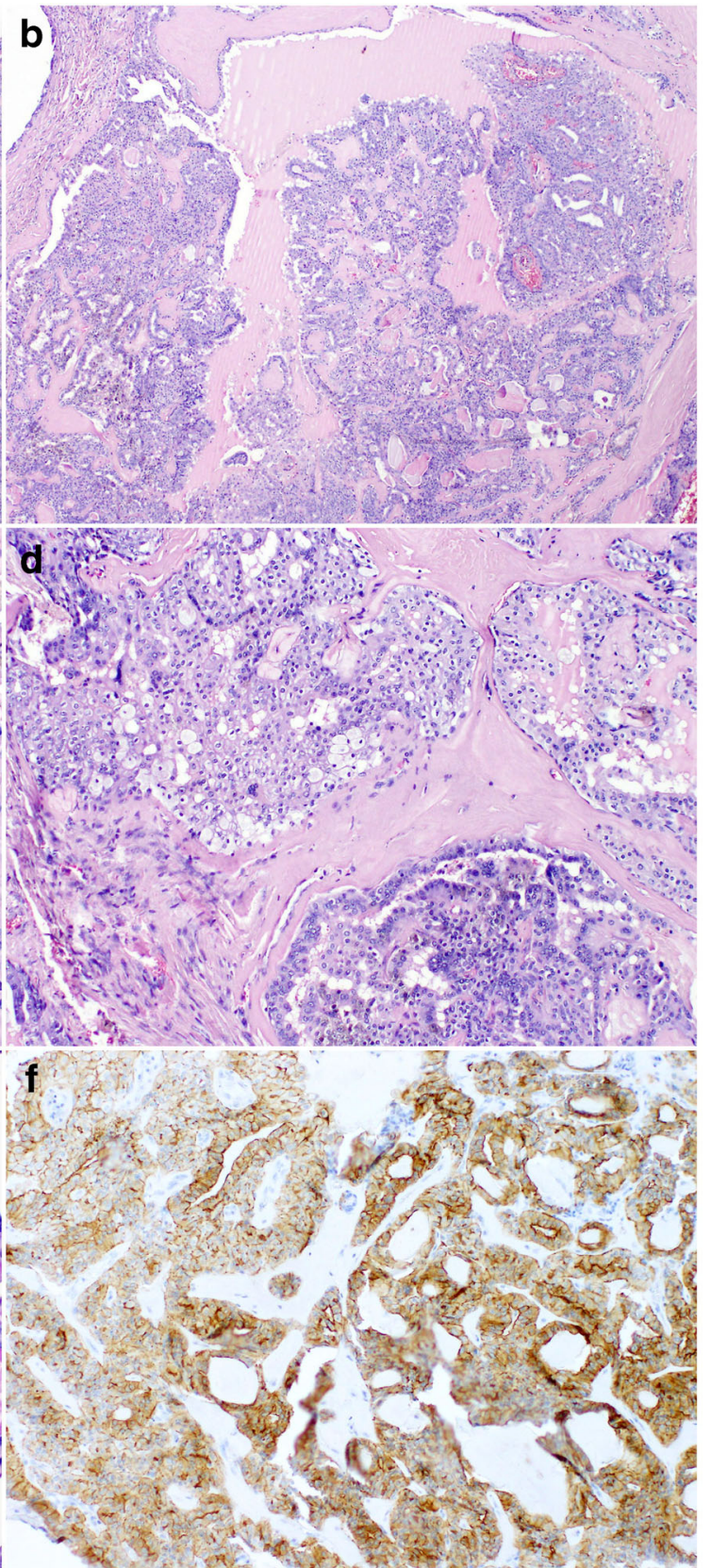

(c H\&E $\times 200 ; \mathbf{d} H \& \mathrm{E} \times 100)$. e Focal mucinous differentiation with PAS-positive vacuoles in the cytoplasm $(H \& E \times 200)$. f Immunohistochemical staining showed strong membranous expression of ALK in $100 \%$ of cells $(H \& E \times 200)$. g Fluorescence in situ hybridization with ALK Dual Color Break Apart FISH Probe. Nuclei with split red and green signals indicate ALK break (yellow arrows). Chromosome 2 with normal gene shows yellow signal (overlapping green and red and white arrows) 
Table 2 Characteristics of eight ALK-positive cases by IHC

\begin{tabular}{|c|c|c|c|c|c|}
\hline Histopathological diagnosis & Localization of ALK IHC staining & $\%$ of positive cells & Staining intensity & FISH & NGS findings \\
\hline Myoepithelial carcinoma & Membranous & $35 \%$ & 3 & Negative & $\begin{array}{l}\text { BFAR c.1780G }>\text { A } \\
\text { NF1 c.7057_7059de }\end{array}$ \\
\hline Adenoid cystic carcinoma & Cytoplasmic & $15 \%$ & 1 & Negative & $\begin{array}{l}\text { ERBB } 2 \text { c. } 601 \mathrm{G}>\mathrm{A} \\
\text { HRAS c. } 484 \mathrm{G}>\mathrm{A} \\
\text { KDR c. } 1298 \mathrm{~A}>\mathrm{G} \\
\text { PTCH1 c. } 1348 \text { splice } \\
\text { RPTOR } \mathrm{c} .2152 \mathrm{C}>\mathrm{T} \\
\text { TP53 c. } 712 \mathrm{~T}>\mathrm{A} \\
\text { TSC } 1 \text { c. } 1060 \mathrm{G}>\mathrm{A}\end{array}$ \\
\hline Basal cell adenocarcinoma & Cytoplasmic & $50 \%$ & 2 & Negative & Negative \\
\hline Adenoid cystic carcinoma & $\begin{array}{l}\text { Cytoplasmic } \\
\text { Nuclear }\end{array}$ & $\begin{array}{l}70 \% \\
5 \%\end{array}$ & $\begin{array}{l}3 \\
1\end{array}$ & Negative & Not diagnostic \\
\hline $\begin{array}{l}\text { Cribriform adenocarcinoma } \\
\text { of minor salivary glands }\end{array}$ & Nuclear & $30 \%$ & 2.3 & Negative & $\begin{array}{l}\text { Low-level amplification } \\
\text { of ALK and ERBB2 }\end{array}$ \\
\hline Adenoid cystic carcinoma & Cytoplasmic & $15 \%$ & 2 & Negative & Negative \\
\hline $\begin{array}{l}\text { Intraductal carcinoma /low grade } \\
\text { cribriform cystadenocarcinoma }\end{array}$ & Membranous & $100 \%$ & 3 & Positive & MYO18A-ALK \\
\hline Basal cell adenocarcinoma & Cytoplasmic & $15 \%$ & 2 & Negative & Negative \\
\hline
\end{tabular}

\section{Next generation sequencing}

All eight tumors positive for ALK IHC were further analyzed by hybrid capture-based NGS. The FISH ALK break-apart positive tumor was found to harbor a novel MYO18A-ALK gene fusion (Fig. 2). The MYO18A-ALK gene fusion was detected in 71 reads encompassing the breakpoint and 17 reads spanning the breakpoint, thus identifying the exact genomic breakpoint of the fusion. The fusion retains exons $1-41$ of
$M Y O 18 A$ and exons $20-29$ of $A L K$, thereby retaining the kinase domain of $A L K$ and the coiled-coil domain of MYO18A.

Among the other seven ALK IHC-positive cases, there was one additional case that showed a low-level gain in $A L K$ with a mean copy number of 4.9 and a low-level $E R B B 2$ gain with a mean copy number of 5.6. These changes occurred in CAMSG, and this tumor showed medium and strong nuclear IHC ALK positivity in $30 \%$ of cells but was negative for $A L K$ rearrangement by break-apart FISH analysis. a

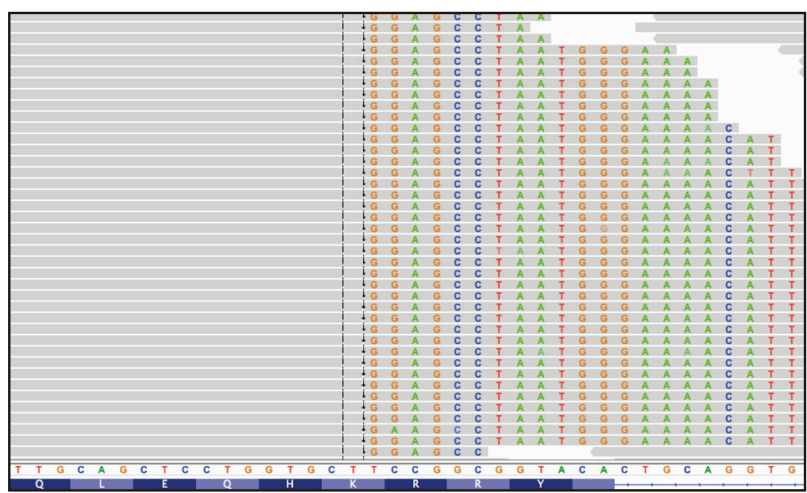

ALK (Exon 20)

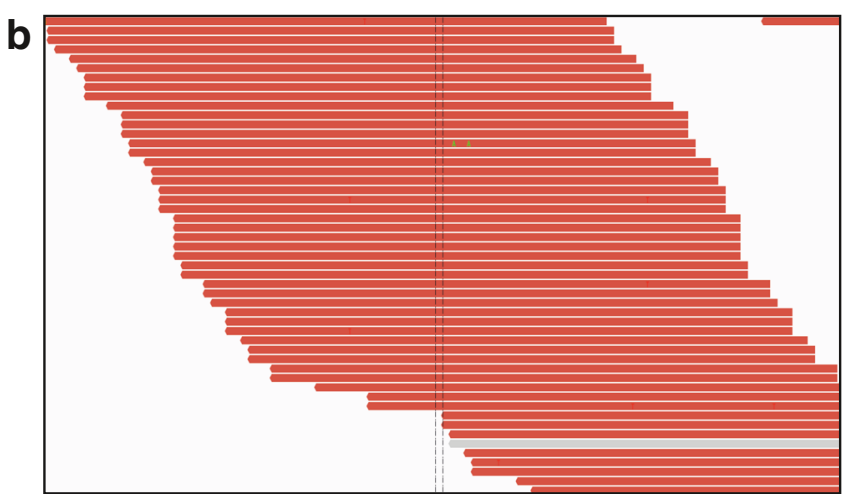

MY018A

C

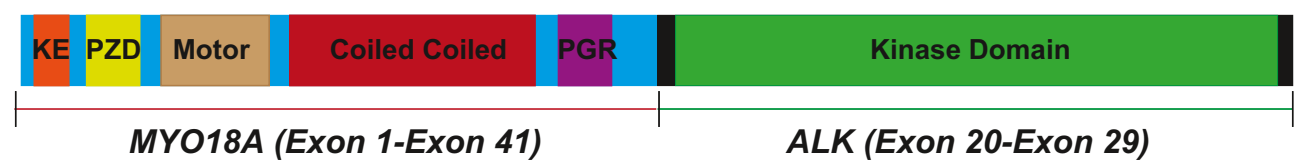

Fig. 2 Identification of the novel MYO18A (Exon1-40)-ALK (exon 2029) gene fusion detected in intraductal carcinoma. a Breakpoint spanning reads in exon 20 of ALK. The spanning reads have both aligned (grey) and misaligned bases (colored). The misaligned bases correspond to a

region of MYO18A. b Encompassing reads in MYO18A (red). The corresponding mate of the reads of MYO18A align to a region in ALK. $\mathbf{c}$ Schematic representation of the MYO18A-ALK gene fusion 
NGS analysis of the remaining seven ALK IHC-positive samples did not indicate any genomic alterations of $A L K$ but resulted in the detection of other important genomic aberrations of potential functional significance, such as inactivating mutations in BRAF (p.D594N) and TP53 (p.C238S), as well as amplifications of ERBB2 (Table 2).

\section{Discussion}

Genomic $A L K$ aberrations are rare in SGCs. Recently, its alterations have been reported in five tumors of this group [18-21]. Out of 182 SGCs we screened by IHC, only eight samples expressed ALK in more than $10 \%$ of tumor cells with moderate to strong staining intensity. FISH and hybrid capture-based next generation sequencing analysis performed in these tumors identified one case with a low-level amplification in the $A L K$ gene (CAMSG with $30 \%$ nuclear positivity). Additionally, one intraductal carcinoma showed $A L K$ rearrangement by FISH, in which a hybrid capture-based next generation sequencing identified the exact genomic breakpoint in a novel $A L K$ and the MYO18A gene fusion on chromosome 17.

Immunohistochemistry (IHC) can be used as a screening method for $A L K$ aberrations, although confirmatory genetic testing is recommended [23, 24]. This is also supported by findings in the recent papers $[19,21]$ in which $A L K$ CTTNA1 and HNRNPH3-ALK translocations were associated with membranous and cytoplasmic ALK staining, respectively. However, neither IHC nor FISH analysis provides information on the exact breakpoint and on the respective fusion partner. For $A L K$-rearranged tumors, the rearrangement partner may correlate with the intracellular localization of the chimeric protein and the pattern of staining. In tumors with NPM1-ALK fusion, ALK protein may be detected in the nucleus and cytoplasm, while in RANBP2-ALK neoplasms, it shows nuclear membrane staining. Fusion proteins TMP3-ALK and CTCL-ALK are found in the cytoplasm, but the former gives diffuse and the latter granular pattern of staining [23]. In our case of IC, the IHC pattern of ALK staining was strongly membranous. In the remaining ALK-positive cases, less intense staining was present in all cellular compartments. This also makes the interpretation of ALK IHC difficult, especially concerning cut-off values that may be taken as an indicator of genetic molecular alterations.

More than 20 different fusion partners of ALK have been described in different neoplasms [23, 25], and their number is still increasing [16, 17, 26, 27]. The type of fusion gene appears to influence not only the subcellular localization but also their biological activity and carcinogenic potential. This variability in localization and activity of $A L K$ is highest in anaplastic lymphoma, in which nine fusion variants have been identified so far. However, multiple fusion partners have been also described in inflammatory myofibroblastic tumor, diffuse large B cell lymphoma, and non-small cell lung carcinoma (NSCLC) [25]. These variants have been discovered only recently, and the knowledge on their biological functions is still limited.

$A L K$-rearranged tumors share characteristic clinicopathological features [14, 23, 25, 27]. $A L K$-rearranged lung adenocarcinomas most often affect middle-aged patients and light or non-smokers. Morphologically, some of these tumors display the characteristic cribriform and signet ring morphology with abundant intracellular mucin $[28,29]$. Similarly, our case of IC showed a cribriform architecture and focal mucinous differentiation with presence of PAS- and mucicarmine-positive microvacuoles. Whether this feature is associated with $A L K$ rearrangement requires studies on a larger series of cases. Taking into consideration the rarity of the tumor, multicenter studies seems to be indicated.

The MYO18A-ALK gene fusion consisted of exons 1-41 of $M Y O 18 A$ and exons 20-29 of $A L K$, thereby retaining the kinase domain of $A L K$ and the coiled-coil domain of MYO18A. Based on functional experimental data from similar $A L K$ fusions, the coiled-coil domain of MYO18A could potentially mediate the dimerization and activation of MYO18A-ALK, thereby resulting in overexpression of constantly activated protein. However, the biological relevance of the novel MYO18A-ALK gene fusion merits further investigation, given potential implications for targeted therapy with ALK inhibitors. In vitro studies might confirm its transforming role, as well as the activation of downstream signaling, and elucidate a possible therapeutic role of different ALK inhibitors. Our patient was not subjected to ALK inhibition as there was no evidence of disease within 8 years after surgery. It is consistent with the indolent clinical behavior characteristics of this tumor as was also reported in another case of ALK-positive IC [20]. However, in the case of SDC with EML4-ALK rearrangement, target treatment resulted in acquired ALK G1202R mutation that led to secondary resistance to ALK inhibitor [21].

The screening of seven additional non-invasive ICs did not disclose ALK positivity by IHC. This suggests lack of the $A L K$ translocation in these tumors and indicates that the MYO18A-ALK gene fusion may be a rare event in these neoplasms. Only analyses of the large series could definitively determine occurrences of this translocation in this tumor type. Interestingly, another translocation in IC was reported by Weinreb et al. [30], who showed NCOA4-RET fusion in one case by NGS and RET rearrangement in two additional cases by FISH in a series of 19 tumors. Recently, Skalova et al. reported NCOA4-RET fusion transcript in 11 cases of intercalated-type IC by NGS [31, 32]. In addition, a novel TRIM27-RET fusion transcript was identified in two ICs with apocrine features. Of note, RET gene was a part of the NGS 
gene panel used in our study (supplementary data), but no $R E T$ changes were detected in the studied cases.

An additional interesting finding in our study was the lowlevel gains in $A L K$ found in the CAMSG. The PRKD3 translocation was detected in this tumor by FISH [22]. In this multicenter study, PRKD1-3 translocation was found in more than $80 \%$ of CAMSGs [33]. In some of those cases, ARIDIA or $D D X 3 X$ was the translocation partner. CAMSG is also a rare entity, with approximately 70 cases described so far. Low-level $A L K$ copy number gain is relatively common in some tumor types, e.g., in alveolar rhabdomyosarcoma [34, 35], in NSCLC [36], and in up to $10 \%$ of renal cell carcinomas [37]. They often reflect chromosome 2 polysomy, rather than true focal amplification [23]. The clinical significance and therapeutic relevance of this finding appear limited. Furthermore, a selection of genomic alterations known from other tumor entities was found in the subset of samples analyzed using hybrid capture-based next generation sequencing. Considering the low number of samples tested comprehensively, it is tempting to speculate that SGCs might harbor more targetable alterations (such as ERBB2 amplifications).

To summarize, we presented a unique extensive analysis of the genetic profile of the salivary gland malignancies showing ALK rearrangements as a rare aberration in these tumors.

Supplementary Information The online version contains supplementary material available at https://doi.org/10.1007/s00428-020-02971-w.

Acknowledgments The preliminary data of our study were presented at the American Association for Cancer Research (AACR) Annual Meeting in April 16-20, 2016, at the New Orleans, Louisiana, USA.

The authors thank Prof. Alena Skalova (Charles University, Faculty of Medicine in Plzen, Czech Republic) for the consultations and valuable comments on the manuscript contents. We would like to thank Prof. Roderick HW Simpson (RS) (University of Calgary, Canada) for providing us a case of intraductal carcinoma (No. 4).

Authors' contributions Hanna Majewska: concept of the paper, histopathological analyses, interpretation of the data, and writing of the manuscript

Adam Stanislaw Gorczynski: concept of the paper, histopathological analyses, interpretation of the data, and writing of the manuscript

Piotr Czapiewski: concept of the paper, histopathological analyses, interpretation of the data, and writing of the manuscript

Roopika Menon: molecular analysis and interpretation of the data (NGS) and revision and acceptance of the manuscript

Judith Mueller: molecular analyses and interpretation of the data (NGS) and revision and acceptance of the manuscript

Sotirios Lakis: molecular analyses and interpretation of the data (NGS) and revision and acceptance of the manuscript

Johannes M Heuckmann: molecular analyses and interpretation of the data (NGS) and revision and acceptance of the manuscript

Jan Laco: donor of the samples and revision and acceptance of the manuscript

Ruta Gupta: donor of the samples and revision and acceptance of the manuscript

Simon Andreasen: donor of the samples and revision and acceptance of the manuscript
Dominik Stodulski: clinical data and revision and acceptance of the manuscript

Mariola Iliszko: molecular analyses and interpretation of the data (FISH)

Rafał Dziadziuszko: concept of the paper and writing of the manuscript

Jacek Jassem: concept of the paper and writing of the manuscript

Lukas C. Heukamp: molecular analyses and interpretation of the data (NGS) and revision and acceptance of the manuscript

Wojciech Biernat: concept of the paper, interpretation of the data, and writing of the manuscript

Funding This study was supported by institutional grants of Medical University of Gdańsk, Poland (02-0095/07/267, 01-0424/08/267, 020023/07/171).

Data availability The sequencing data was deposited in the NCBI Sequence Read Archive to be released upon publication (BioProject Accession: PRJNA646228).

\section{Compliance with ethical standards}

Conflict of interest Prof Rafał Dziadziuszko: Advisory board role for Pfizer, Novartis, Roche, Takeda, Merck, Seattle Genetics, and Foundation Medicine. Travel costs from Roche and AstraZeneca. Dr. Johannes Heuckmann is a full time employee of NEO New Oncology $\mathrm{GmbH}$. Prof Jacek Jassem: Advisory board role for Boehringer, Astra Zeneca, BMS, and Merck. Other authors declare that they have no conflict of interest.

Ethics approval The study was approved by the Independent Bioethics Committee for Scientific Research at Medical University of Gdańsk (Decision number: NKBBN/4182015)

Consent to participate Not applicable.

Consent for publication Not applicable.

Code availability Not applicable.

Open Access This article is licensed under a Creative Commons Attribution 4.0 International License, which permits use, sharing, adaptation, distribution and reproduction in any medium or format, as long as you give appropriate credit to the original author(s) and the source, provide a link to the Creative Commons licence, and indicate if changes were made. The images or other third party material in this article are included in the article's Creative Commons licence, unless indicated otherwise in a credit line to the material. If material is not included in the article's Creative Commons licence and your intended use is not permitted by statutory regulation or exceeds the permitted use, you will need to obtain permission directly from the copyright holder. To view a copy of this licence, visit http://creativecommons.org/licenses/by/4.0/.

\section{References}

1. El-Naggar AK, Chan JKC, Grandis JR, Takata T, Slootweg PJ (2017) World Health Organization classification of head and neck tumours. IARC, Lyon

2. Schwarz S, Stiegler C, Muller M, Ettl T, Brockhoff G, Zenk J, Agaimy A (2011) Salivary gland mucoepidermoid carcinoma is a 
clinically, morphologically and genetically heterogeneous entity: a clinicopathological study of 40 cases with emphasis on grading, histological variants and presence of the $\mathrm{t}(11 ; 19)$ translocation. Histopathology 58:557-570

3. Stenman G (2013) Fusion oncogenes in salivary gland tumors: molecular and clinical consequences. Head Neck Pathol 7(Suppl 1):S12-S19

4. O'Neill ID (2009) $\mathrm{t}(11 ; 19)$ translocation and CRTC1-MAML2 fusion oncogene in mucoepidermoid carcinoma. Oral Oncol 45:2-9

5. Majewska H, Skalova A, Stodulski D, Klimkova A, Steiner P, Stankiewicz C, Biernat W (2015) Mammary analogue secretory carcinoma of salivary glands: a new entity associated with ETV6 gene rearrangement. Virchows Arch 466:245-254. https://doi.org/ 10.1007/s00428-014-1701-8

6. Skalova A, Vanecek T, Sima R, Laco J, Weinreb I, Perez-Ordonez B, Starek I, Geierova M, Simpson RH, Passador-Santos F, Ryska A, Leivo I, Kinkor Z, Michal M (2010) Mammary analogue secretory carcinoma of salivary glands, containing the ETV6-NTRK3 fusion gene: a hitherto undescribed salivary gland tumor entity. Am J Surg Pathol 34:599-608

7. Persson M, Andren Y, Mark J, Horlings HM, Persson F, Stenman G (2009) Recurrent fusion of MYB and NFIB transcription factor genes in carcinomas of the breast and head and neck. Proc Natl Acad Sci U S A 106:18740-18744

8. Mitani Y, Liu B, Rao PH, Borra VJ, Zafereo M, Weber RS, Kies M, Lozano G, Futreal PA, Caulin C, El-Naggar AK (2016) Novel MYBL1 gene rearrangements with recurrent MYBL1-NFIB fusions in salivary adenoid cystic carcinomas lacking $\mathrm{t}(6 ; 9)$ translocations. Clin Cancer Res 22:725-733. https://doi.org/10.1158/ 1078-0432.CCR-15-2867-T

9. Antonescu CR, Katabi N, Zhang L, Sung YS, Seethala RR, Jordan RC, Perez-Ordonez B, Have C, Asa SL, Leong IT, Bradley G, Klieb H, Weinreb I (2011) EWSR1-ATF1 fusion is a novel and consistent finding in hyalinizing clear-cell carcinoma of salivary gland. Genes Chromosom Cancer 50:559-570

10. Skalova A, Weinreb I, Hyrcza M, Simpson RH, Laco J, Agaimy A, Vazmitel M, Majewska H, Vanecek T, Talarcik P, Manajlovic S, Losito SN, Steiner P, Klimkova A, Michal M (2015) Clear cell myoepithelial carcinoma of salivary glands showing EWSR1 rearrangement: molecular analysis of 94 salivary gland carcinomas with prominent clear cell component. Am J Surg Pathol 39:338-348

11. Morris SW, Kirstein MN, Valentine MB, Dittmer KG, Shapiro DN, Saltman DL, Look AT (1994) Fusion of a kinase gene, ALK, to a nucleolar protein gene, NPM, in non-Hodgkin's lymphoma. Science 263:1281-1284

12. Wang Y, Wang S, Xu S, Qu J, Liu B (2014) Clinicopathologic features of patients with non-small cell lung cancer harboring the EML4-ALK fusion gene: a meta-analysis. PLoS One 9:e110617

13. Walther C, Hofvander J, Nilsson J, Magnusson L, Domanski HA, Gisselsson D, Tayebwa J, Doyle LA, Fletcher CD, Mertens F (2015) Gene fusion detection in formalin-fixed paraffin-embedded benign fibrous histiocytomas using fluorescence in situ hybridization and RNA sequencing. Lab Investig 95:1071-1076

14. Park G, Kim TH, Lee HO, Lim JA, Won JK, Min HS, Lee KE, Park DJ, Park YJ, Park WY (2015) Standard immunohistochemistry efficiently screens for anaplastic lymphoma kinase rearrangements in differentiated thyroid cancer. Endocr Relat Cancer 22:55-63

15. Chou A, Fraser S, Toon CW, Clarkson A, Sioson L, Farzin M, Cussigh C, Aniss A, O'Neill C, Watson N, Clifton-Bligh RJ, Learoyd DL, Robinson BG, Selinger CI, Delbridge LW, Sidhu SB, O'Toole SA, Sywak M, Gill AJ (2015) A detailed clinicopathologic study of ALK-translocated papillary thyroid carcinoma. Am J Surg Pathol 39:652-659

16. Kim SM, Kim MJ, Jung HA, Sun JM, Choi YL, Ko YH, Park K, Baek CH, Son YI, Ahn MJ (2015) Presence of anaplastic lymphoma kinase translocation in sarcomatoid carcinoma of head and neck and treatment effect of crizotinib: a case series. Head Neck 37:E66E69

17. Cajaiba MM, Jennings LJ, Rohan SM, Perez-Atayde AR, MarinoEnriquez A, Fletcher JA, Geller JI, Leuer KM, Bridge JA, Perlman EJ (2016) ALK-rearranged renal cell carcinomas in children. Genes Chromosom Cancer 55:442-451

18. Dalin MG, Katabi N, Persson M, Lee KW, Makarov V, Desrichard A, Walsh LA, West L, Nadeem Z, Ramaswami D, Havel JJ, Kuo F, Chadalavada K, Nanjangud GJ, Ganly I, Riaz N, Ho AL, Antonescu CR, Ghossein R, Stenman G, Chan TA, Morris LGT (2017) Multi-dimensional genomic analysis of myoepithelial carcinoma identifies prevalent oncogenic gene fusions. Nat Commun 8: 1197. https://doi.org/10.1038/s41467-017-01178-z

19. Sasaki E, Masago K, Fujita S, Suzuki H, Hanai N, Hosoda W (2020) Salivary secretory carcinoma harboring a novel ALK fusion: expanding the molecular characterization of carcinomas beyond the ETV6 gene. Am J Surg Pathol. https://doi.org/10.1097/PAS. 0000000000001471

20. Rooper LM, Thompson LDR, Gagan J, Oliai BR, Weinreb I, Bishop JA (2020) Salivary intraductal carcinoma arising within intraparotid lymph node: a report of 4 cases with identification of a novel STRN-ALK fusion. Head Neck Pathol. https://doi.org/10. 1007/s12105-020-01198-0

21. Dogan S, Ng CKY, Xu B, Kumar R, Wang L, Edelweiss M, Scott SN, Zehir A, Drilon A, Morris LGT, Lee NY, Antonescu CR, Ho AL, Katabi N, Berger MF, Reis-Filho JS (2019) The repertoire of genetic alterations in salivary duct carcinoma including a novel HNRNPH3-ALK rearrangement. Hum Pathol 88:66-77. https:// doi.org/10.1016/j.humpath.2019.03.004

22. Majewska H, Skalova A, Weinreb I, Stodulski D, Hyrcza M, Stankiewicz C, Biernat W (2016) Giant cribriform adenocarcinoma of the tongue showing PRKD3 rearrangement. Pol J Pathol 67:84 90

23. Marino-Enriquez A, Dal CP (2013) ALK as a paradigm of oncogenic promiscuity: different mechanisms of activation and different fusion partners drive tumors of different lineages. Cancer Genet 206:357-373

24. von Laffert M, Warth A, Penzel R, Schirmacher P, Kerr KM, Elmberger G, Schildhaus HU, Buttner R, Lopez-Rios F, Reu S, Kirchner T, Pauwels P, Specht K, Drecoll E, Hofler H, Aust D, Baretton G, Bubendorf L, Stallmann S, Fisseler-Eckhoff A, Soltermann A, Tischler V, Moch H, Penault-Llorca F, Hager H, Schaper F, Lenze D, Hummel M, Dietel M (2014) Multicenter immunohistochemical ALK-testing of non-small-cell lung cancer shows high concordance after harmonization of techniques and interpretation criteria. J Thorac Oncol 9:1685-1692

25. Gorczynski A, Prelowska M, Adam P, Czapiewski P, Biernat W (2014) ALK-positive cancer: still a growing entity. Future Oncol 10:305-321. https://doi.org/10.2217/fon. 13.184

26. Loharamtaweethong K, Puripat N, Aoonjai N, Sutepvarnon A, Bandidwattanawong C (2016) Anaplastic lymphoma kinase (ALK) translocation in paediatric malignant peritoneal mesothelioma: a case report of novel ALK-related tumour spectrum. Histopathology 68:603-607

27. Olsen TK, Panagopoulos I, Meling TR, Micci F, Gorunova L, Thorsen J, Due-Tonnessen B, Scheie D, Lund-Iversen M, Krossnes B, Saxhaug C, Heim S, Brandal P (2015) Fusion genes with ALK as recurrent partner in ependymoma-like gliomas: a new brain tumor entity? Neuro-Oncology 17:1365-1373

28. McLeer-Florin A, Moro-Sibilot D, Melis A, Salameire D, Lefebvre C, Ceccaldi F, de Fraipont F, Brambilla E, Lantuejoul S (2012) Dual IHC and FISH testing for ALK gene rearrangement in lung adenocarcinomas in a routine practice: a French study. J Thorac Oncol 7:348-354

29. Park HS, Lee JK, Kim DW, Kulig K, Kim TM, Lee SH, Jeon YK, Chung DH, Heo DS (2012) Immunohistochemical screening for 
anaplastic lymphoma kinase (ALK) rearrangement in advanced non-small cell lung cancer patients. Lung Cancer 77:288-292

30. Weinreb I, Bishop JA, Chiosea SI, Seethala RR, Perez-Ordonez B, Zhang L, Sung YS, Chen CL, Assaad A, Oliai BR, Antonescu CR (2018) Recurrent RET gene rearrangements in intraductal carcinomas of salivary gland. Am J Surg Pathol 42:442-452

31. Skalova A, Ptakova N, Santana T, Agaimy A, Ihrler S, Uro-Coste E, Thompson LDR, Bishop JA, Baneckova M, Rupp NJ, Morbini P, de Sanctis S, Schiavo-Lena M, Vanecek T, Michal M, Leivo I (2019) NCOA4-RET and TRIM27-RET are characteristic gene fusions in salivary intraductal carcinoma, including invasive and metastatic tumors: is "intraductal" correct? Am J Surg Pathol 43:13031313. https://doi.org/10.1097/PAS.0000000000001301

32. Skalova A, Vanecek T, Uro-Coste E, Bishop JA, Weinreb I, Thompson LDR, de Sanctis S, Schiavo-Lena M, Laco J, Badoual C, Santana CT, Ptakova N, Baneckova M, Miesbauerova M, Michal M (2018) Molecular profiling of salivary gland intraductal carcinoma revealed a subset of tumors harboring NCOA4-RET and novel TRIM27-RET fusions: a report of 17 cases. Am J Surg Pathol 42:1445-1455. https://doi.org/10.1097/PAS.0000000000001133

33. Weinreb I, Zhang L, Tirunagari LM, Sung YS, Chen CL, PerezOrdonez B, Clarke BA, Skalova A, Chiosea SI, Seethala RR, Waggott D, Boutros PC, How C, Liu FF, Irish JC, Goldstein DP, Gilbert R, Ud DN, Assaad A, Hornick JL, Thompson LD, Antonescu CR (2014) Novel PRKD gene rearrangements and variant fusions in cribriform adenocarcinoma of salivary gland origin. Genes Chromosom Cancer 53:845-856
34. van Gaal JC, Flucke UE, Roeffen MH, de Bont ES, Sleijfer S, Mavinkurve-Groothuis AM, Suurmeijer AJ, van der Graaf WT, Versleijen-Jonkers YM (2012) Anaplastic lymphoma kinase aberrations in rhabdomyosarcoma: clinical and prognostic implications. J Clin Oncol 30:308-315

35. Gasparini P, Casanova M, Villa R, Collini P, Alaggio R, Zin A, Bonvini P, Antonescu CR, Boldrini R, Caserini R, Moro M, Centonze G, Meazza C, Massimino M, Bergamaschi L, Luksch R, Chiaravalli S, Bisogno G, Zaffaroni N, Daidone MG, Sozzi G, Ferrari A (2016) Anaplastic lymphoma kinase aberrations correlate with metastatic features in pediatric rhabdomyosarcoma. Oncotarget 7:58903-58914

36. Salido M, Pijuan L, Martinez-Aviles L, Galvan AB, Canadas I, Rovira A, Zanui M, Martinez A, Longaron R, Sole F, Serrano S, Bellosillo B, Wynes MW, Albanell J, Hirsch FR, Arriola E (2011) Increased ALK gene copy number and amplification are frequent in non-small cell lung cancer. J Thorac Oncol 6:21-27

37. Sukov WR, Hodge JC, Lohse CM, Akre MK, Leibovich BC, Thompson RH, Cheville JC (2012) ALK alterations in adult renal cell carcinoma: frequency, clinicopathologic features and outcome in a large series of consecutively treated patients. Mod Pathol 25: $1516-1525$

Publisher's note Springer Nature remains neutral with regard to jurisdictional claims in published maps and institutional affiliations. 